\title{
Successful and Effective Six Sigma Implementation in the Manufacturing Industry
}

\author{
Syed Talib Haider, Hiyam Al-Kilidar and Rene Leveaux
}

University of Technology, Sydney, Australia

\author{
Received date: 10 October 2017; Accepted date: 14 December 2017; \\ Published date: 12 November 2018 \\ Academic Editor: Faezah Binti Othman \\ Copyright (C) 2018. Syed Talib Haider, Hiyam Al-Kilidar and Rene Leveaux . Distributed under \\ Creative Commons CC-BY 4.0
}

\begin{abstract}
Organizational performance in the manufacturing industry is directly influenced by quality; and through an examination of literature, critical success factors that lead to the implementation of six-sigma in the manufacturing industry are identified for organizations of different sizes: SMEs, large enterprises and general/ unspecified organizations (not identified as either SMEs or Large in literature). The general success factors across organizations (unspecified) were found to include Employee Education/Training, Top Management Commitment, Project Selection, Employee Involvement/Communication, and Project Management/Leadership. For the large enterprises, the following factors were identified: Project Selection, Alignment with Customer Requirements, Employee Education/Training, Senior Management Commitment, Use of Quality Tools, and Visible Cost Saving. This work provides a platform to gain a deeper understanding of the requirements necessary to ensure the successful implementation of six-sigma in organizations, and where best to direct resources.
\end{abstract}

Keywords Quality, Sigma Six, Critical Success Factors

\section{Introduction}

The concept of quality has been defined in various ways, for example, Abott (1955) defines it classically as value (Abott, 1955); and others as conformance to specifications and/or requirements (Gilmore, 1974, Crosby \& Free 1979), as fitness for use (Juran 1988) and as meeting and/or exceeding customers' expectations
(Gronroos 1982 and Reeves \& Bednar 1994). The concept of quality is not new; however, as demonstrated above, all definitions are open to various interpretations and may be considered as highly subjective.

Harry (1998) defines "Six-sigma" as an assertive strategy for a firm to achieve classical definitions of quality. The variable

Cite this Article as: Syed Talib Haider, Hiyam Al-Kilidar and Rene Leveaux (2018)," Successful and Effective Six Sigma Implementation in the Manufacturing Industry",The Journal of Organizational Management Studies, Vol. 2018 (2018), Article ID 517249, DOI: 10.5171/2018.517249 
$\sigma$ (sigma) is chiefly associated with variance in statistics; indicating the degree to which a quantity varies from its mean or average value (Pande, Neuman \& Cavanagh 2000). When a quantity is within six standard deviations of its mean (three deviations above and three deviations below), it is said to be within the six sigma limits. The term, in manufacturing, is used to understand the variability of a manufacturing process used to produce a product.

The importance of quality is stressed when it is linked with firm performance. Research indicates that Total Quality Management (TQM) is linked with positive firm performance (Kaynak 2003; Samson \& Terziovski 1999). This is not limited to large-scale organizations as indicated by O'Neli, Sohal and Teng (2016) who concluded that small-scale manufacturing concerns are also positively affected in terms of firm performance when there is high emphasis on quality.

To unravel recent advances in the six sigma domain, an examination of literature published over a 20-year period (1996 to 2016) was carried out in relation to the question of how quality may be implemented in the manufacturing industry. The aim was to identify critical success factors in implementing quality in the manufacturing industry that lead to improved performance of manufacturing projects.

\section{Literature Review}

Previously identified success factors for quality implementation in the manufacturing industry were determined via a review of the literature. The search used the three key word descriptors: "Six Sigma", "Quality Improvement" and "Manufacturing". The search was limited to the years 1996 to 2016 and was run through the Scopus database. A total of 87 results were retrieved, which were filtered further based on relevance and journal ranking. Only top tier (Q1 and Q2 in SJR rankings) peer reviewed journals were selected. While relevance was determined on the topic of the paper, papers that focused, for example, on a specific process were excluded, resulting in a total of 28 research papers based on various countries around the world to be finally analyzed, as may be seen in Table 1 . The most notable countries represented in this research are Australia, China, India, Mexico, Italy, France, USA and the UK. 
Table 1: Relevant factors considered in this work

\begin{tabular}{|c|c|c|c|c|c|c|c|c|c|c|c|c|c|c|c|c|c|c|c|}
\hline & $\begin{array}{l}\text { Industry } \\
\text { Type }\end{array}$ & 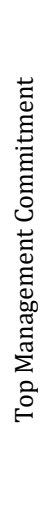 & 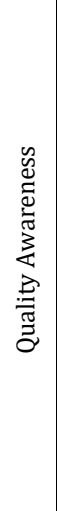 & 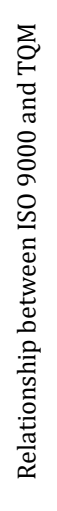 & 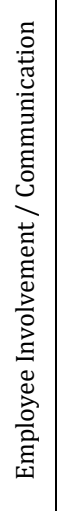 & 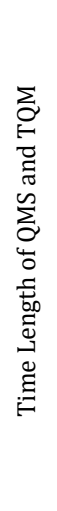 & 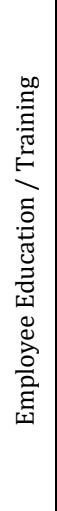 & 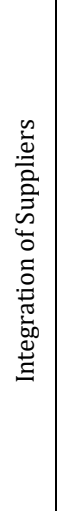 & 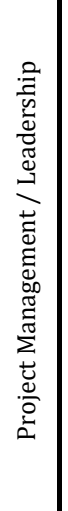 & 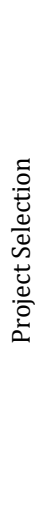 & 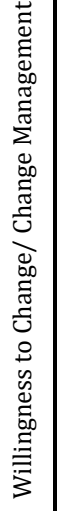 & 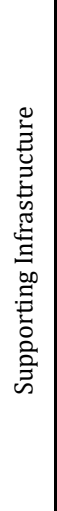 & 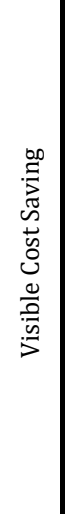 & 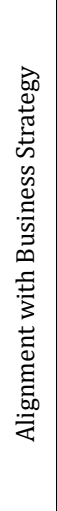 & 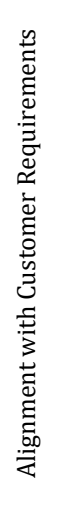 & 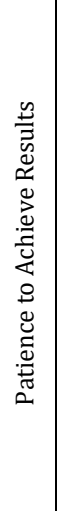 & 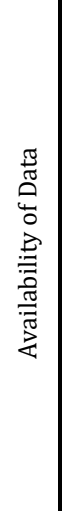 & 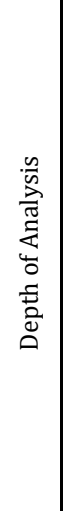 & 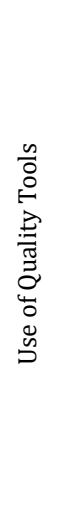 \\
\hline $\begin{array}{c}\text { Hendricks \& } \\
\text { Kelbaugh (1998) } \\
\end{array}$ & Large & * & $*$ & & * & & $*$ & $*$ & $*$ & $*$ & $*$ & * & * & * & & & * & & \\
\hline$\underline{\text { Hua et al. }(2000)}$ & $\begin{array}{c}\text { General/ } \\
\text { Unspecified }\end{array}$ & $*$ & $*$ & & $*$ & $*$ & $*$ & & & & & & & & & & & & \\
\hline$\frac{\text { Hahn, Doganaksoy }}{\text { \& Hoerl }(2000)}$ & $\begin{array}{c}\text { General/ } \\
\text { Unspecified }\end{array}$ & * & & & & & $*$ & * & & $*$ & & & * & & & $*$ & & * & * \\
\hline$\frac{\text { Banuelas Coronado }}{\text { \& Antony (2002) }}$ & $\begin{array}{c}\text { General/ } \\
\text { Unspecified }\end{array}$ & $*$ & & & $*$ & & $*$ & & * & $*$ & $*$ & $*$ & & * & * & & & & * \\
\hline$\frac{\text { Antony \& Banuelas }}{(2002)}$ & $\begin{array}{c}\text { General/ } \\
\text { Unspecified }\end{array}$ & $*$ & & & & & $*$ & & * & $*$ & $*$ & $*$ & & * & $*$ & & & & $*$ \\
\hline Gijo \& Rao (2005) & $\begin{array}{c}\text { General/ } \\
\text { Unspecified }\end{array}$ & & & & $*$ & & $*$ & & & $*$ & & $*$ & & & * & $*$ & $*$ & & \\
\hline $\begin{array}{c}\text { Banuelas, Antony \& } \\
\text { Brace }(2005)\end{array}$ & $\begin{array}{c}\text { General/ } \\
\text { Unspecified }\end{array}$ & $*$ & & & * & & * & & * & $*$ & & & & & & * & & & * \\
\hline Hahn (2005) & Large & & & & $*$ & & $*$ & & & $*$ & & & & & * & $*$ & & & \\
\hline $\begin{array}{c}\frac{\text { Brady \& Allen }}{(2006)} \\
\end{array}$ & $\begin{array}{c}\text { General/ } \\
\text { Unspecified }\end{array}$ & * & & & * & & $*$ & & * & $*$ & $*$ & & & & * & * & & & \\
\hline$\frac{\text { Kwak \& Anbari }}{(2006)}$ & $\begin{array}{c}\text { General/ } \\
\text { Unspecified }\end{array}$ & * & & & & & $*$ & & & $*$ & $*$ & & & & & & & & \\
\hline$\frac{\text { Antony, Kumar \& }}{\text { Labib }(2008)}$ & SME & * & & & $*$ & & * & & & $*$ & & * & & * & & & & & * \\
\hline$\frac{\text { Kumar \& Antony }}{(2008 \mathrm{a})}$ & SME & $*$ & & & $*$ & & $*$ & & * & $*$ & $*$ & $*$ & & * & $*$ & & & & $*$ \\
\hline$\frac{\text { van Iwaarden et al. }}{(2008)}$ & $\begin{array}{c}\text { General/ } \\
\text { Unspecified }\end{array}$ & $*$ & & & $*$ & & $*$ & & * & & & & & & * & $*$ & & & \\
\hline$\frac{\text { Antony \& Desai }}{(2009)}$ & Large & $*$ & & & & & $*$ & & $*$ & $*$ & * & $*$ & & $*$ & $*$ & $*$ & & & $*$ \\
\hline $\begin{array}{c}\text { Gray \& } \\
\text { Anantatmula } \\
(2009)\end{array}$ & $\begin{array}{c}\text { General/ } \\
\text { Unspecified }\end{array}$ & $*$ & & & $*$ & & $*$ & & $*$ & & & & & & * & $*$ & & & \\
\hline $\begin{array}{c}\text { Kumar, Antony \& } \\
\text { Douglas (2009) } \\
\end{array}$ & SME & $*$ & & & $*$ & & $*$ & & & $*$ & $*$ & $*$ & & * & & & & & \\
\hline $\begin{array}{c}\text { Zu, Robbins \& } \\
\text { Fredendall }(2010)\end{array}$ & $\begin{array}{c}\text { General/ } \\
\text { Unspecified }\end{array}$ & $*$ & & & $*$ & & $*$ & & $*$ & & & & & & & $*$ & & & \\
\hline$\frac{\text { Tkáč \& Lyócsa }}{(2010)}$ & $\begin{array}{c}\text { General/ } \\
\text { Unspecified }\end{array}$ & * & & & & & $*$ & & * & $*$ & $*$ & $*$ & & $*$ & $*$ & & & & $*$ \\
\hline Brun (2011) & $\begin{array}{c}\text { General/ } \\
\text { Unspecified }\end{array}$ & $*$ & & & $*$ & & $*$ & & * & $*$ & $*$ & $*$ & & $*$ & & & & & $*$ \\
\hline$\underline{\text { Mehrjerdi (2011) }}$ & $\begin{array}{c}\text { General/ } \\
\text { Unspecified }\end{array}$ & * & & & $*$ & & $*$ & & * & $*$ & & & & & & * & & & * \\
\hline $\begin{array}{l}\underline{\text { Antony, Gijo \& }} \\
\text { Childe (2012a) }\end{array}$ & Large & * & & & & & & & * & $*$ & $*$ & & $*$ & * & * & & & & $*$ \\
\hline
\end{tabular}

Syed Talib Haider, Hiyam Al-Kilidar and Rene Leveaux (2018), The Journal of Organizational Management Studies,DOI: 10.5171/2018.517249 


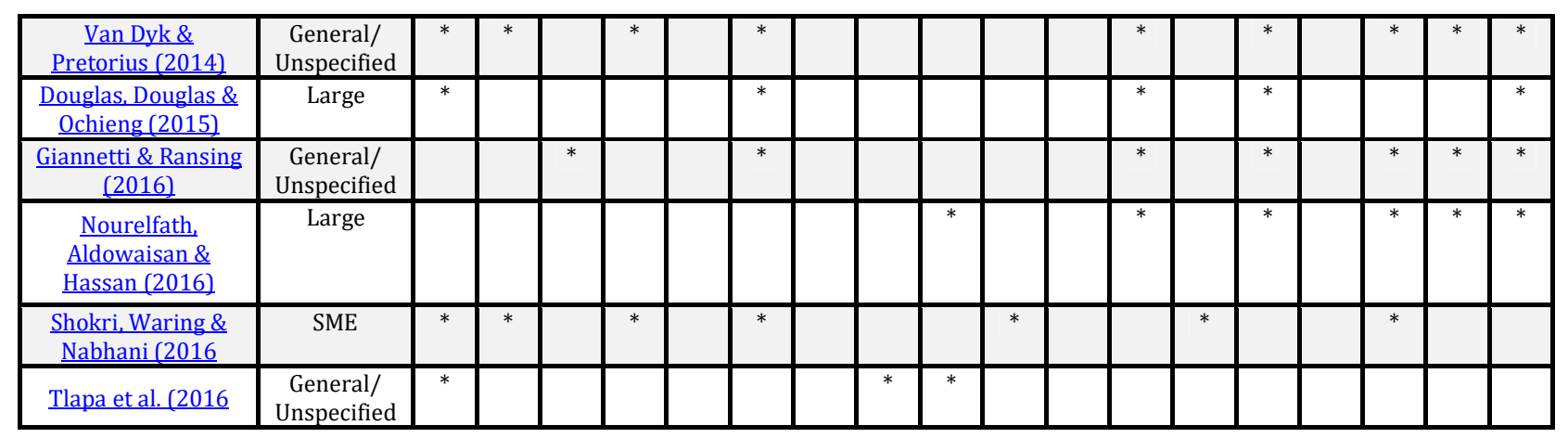

The identified factors were further divided by the size of organization into three categories:

1. Large Enterprises - organizations with an employee count in excess of 199 employees

2. SMEs - organizations with an employee count of less than 200 employees.

3. General / unspecified organisation size was NOT specifically mentioned in research.

The size of companies is based on the number of employees according to
Australian Bureau of Statistics. Any company with less than 200 employees is regarded as an SME and any company with 200 employees or more is classified as a large enterprise (ABS 2016).

The following hypothesis was tested:

H1. Similar critical success factors are shared by SMEs and large enterprises.

Figure 1 below illustrates the identified success factors derived from an analysis of the literature reviewed for the three categories of organization sizes. 


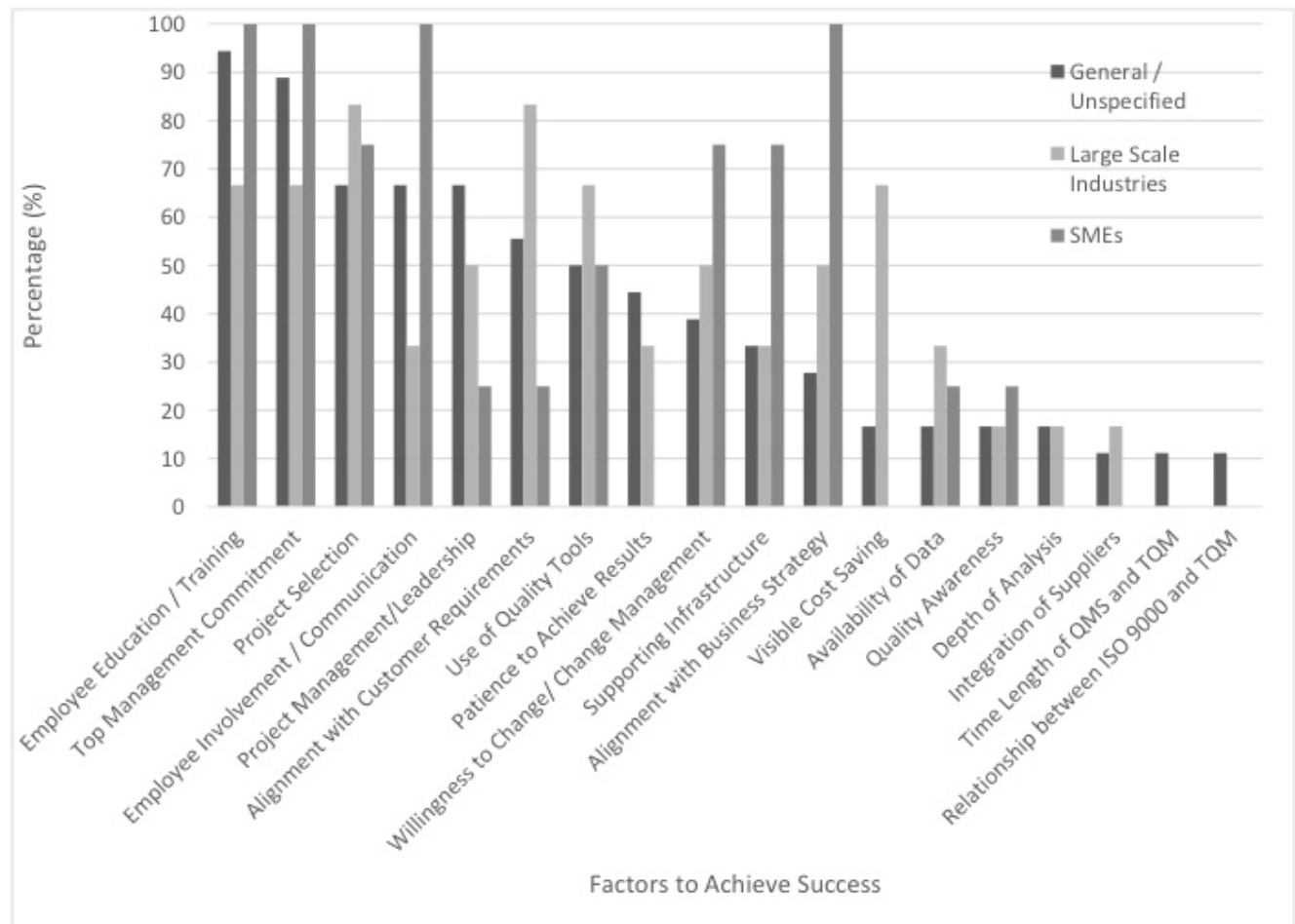

Figure 1: Analysis of literature for all industries

The percentages shown in Figure 1 were calculated by simply dividing the number of times a factor has appeared for a particular industry by the number of papers that have been identified for that industry. For example, Employee Education/Training has been identified by 17 articles in the general/unspecified category while the total number of papers that cited that category are 18 . This gives a percentage of approximately $94 \%$.

Following the sorting of the data, the hypothesis was examined by analyzing the identified percentages.

\section{Discussion}

Critical success factors have been widely used in management studies. They are largely associated with the ability of an organization to strategically perform well. Freund (1988) has stated that these must be:

a. Important to achieve overall goals of the organization,

b. Measurable and controllable by the organization,

c. Relatively few in number,

d. Expressed as things that must be done,

e. Applicable to all companies in the industry with similar objectives and strategies and,

f. Hierarchical in nature.

Other researchers, off course, have differed with that view, for example, Bullen \& Rockart (1981) identified critical success factors as being specific to a manager which means that managers would be able to identify factors critical to their own performance.

Since six-sigma engulfs an entire organization as explained by Hendricks \& Kelbaugh (1998), the first view is more relevant to this study; i.e. identifying critical success factors that define an organization's overall strategy. 
Having said that, it is important to understand what methods have been used to determine these factors and what has been the effectiveness of those methods. Leidecker \& Bruno (1984) recognized the following six methods of identifying factors that are critical to an organization's success:
a. Environmental analysis,
b. Analysis of industry structure,
c. Industry/business experts,
d. Analysis of competition,
e. Analysis of dominant firm in the industry, and
f. Company assessment and PIMS (profit impact of market strategy) results.

While this seems to be an exhaustive process, it can be made a lot easier simply by conducting two to three interview sessions of a company's top executives (Rockart 1978). This helps in determining where management's attention needs to be directed, and limiting the amount of data required todevelop measures for the critical success factors.

As with other factors that are necessary for organizational success, it was pointed out earlier that quality improvement has been positively linked to firm performance (Kaynak 2003; Samson \& Terziovski 1999). One of the most successful adaptations of quality improvement practices has been by General Electric and Motorola who managed to save the respective organizations billions of dollars (Hendricks \& Kelbaugh 1998). Some might argue that Motorola has not done too well since then, however, that had very little to do with their success with six-sigma. Instead, Motorola's demise as the first choice mobile phone was a result of other strategic decisions.

Figure 1 classifies success factors in the literature. The more prolific ones are described below:

\section{Employee Education and Training}

Wiley (1997) identified that one of the major motivators for employee performance is when employees perform tasks that encourage growth. Coupled with top management commitment, when managers communicate the importance of a particular training to the organization, employees show more willingness to learn and do better (Tsai \& Tai 2003). It is for this reasons that (Van Dyk \& Pretorius 2014) considered Employee Education and Training as critical for the sustainability of a quality improvement initiative within an organization. Researchers, however, remain divided on the type of industry. While Antony \& Desai (2009) associate it with large-scale enterprises, Shokri, Waring \& Nabhani (2016) associate it with SMEs and Giannetti \& Ransing (2016) chose to abstain from identifying the size of the industry.

\section{Top Management Commitment}

Successful implementation of six-sigma program leads to improved firm performance (Kaynak 2003; Samson \& Terziovski 1999). . One of the requirements of the six-sigma program is that it is implemented throughout the organization. This can be explained by considering Edward Deming's need for constancy of purpose. If top management does not commit to implementing sixsigma within the organization, this will lead to a lack of direction (Gijo \& Rao 2005). Various authors have identified the importance of top management commitment through different studies (Antony \& Desai 2009; Antony, Kumar \& Labib 2008; Hua et al. 2000). However, some have stressed more importance on it than others. This is largely based on industry type. For example, various authors have identified Top Management Commitment as necessary for SMEs (Kumar, Antony \& Douglas 2009), some for Large Scale Organisations (Douglas, Douglas \& Ochieng 2015; Hendricks \& Kelbaugh 1998) while others have considered a mix of industries (small and large) (Gray \& Anantatmula 2009; Tlapa et al. 2016).

\section{Project Selection}

For an organization to survive, the places 
where it chooses to invest its resources remain highly critical to its sustainability (Bower 1970). Kumar, et. al (2009) stressed having an important framework within an organization which helps in selecting projects that contribute best towards the effectiveness of the six-sigma program. There are various methods that have been identified through research that help in selecting appropriate projects (Meade \& Presley 2002). However, they are beyond the scope of this study.

What is relevant however, is the size of industries this factor is attributable to. Not surprisingly both SMEs (Kumar, Antony \& Douglas 2009) and Large-scale Enterprises (Hendricks \& Kelbaugh 1998) consider it important. A wide array of authors does not associate any size of industry to it while considering it important to the successful implementation of the quality improvement project (Kwak \& Anbari 2006; Tkáč \& Lyócsa 2010) which suggests its importance across all industries regardless of the size.

\section{Project Management}

Projects vary in size and type depending on industry. It is, therefore, important to have good management practices that govern projects (Cooke-Davies 2002). Six-sigma uses a variety of improvement experts, which are differentiated as green belts, black belts, master black belts and project champions. They act as project managers and undertake special training that is specific to six-sigma project management (Linderman et al. 2003). It is for this reason that many researchers have considered project management as a critical part of the quality improvement process. Antony et.al (2007) , for example, evaluated the essential characteristics that are required by these project manages, and, as with other factors that have been discussed so far, researchers concluded that project management is an important part of the quality improvement program regardless of the size of organization. Research conducted regardless of the organizational size consists heavily of those that consider project management a vital part of an organization's quality improvement program (Brady \& Allen 2006; Hassan, Marimuthu \& Mahinderjit-Singh 2016; Zu, Robbins \& Fredendall 2010). Others have attributed its importance for both SMEs (Kumar \& Antony 2008) and large enterprises (Hendricks \& Kelbaugh 1998).

\section{Alignment with Customer Requirements}

"The customer is king and knows it" (Fredericks \& Salter II 1998), is among the famous statements that are in circulation today. It is important to conduct a customer value chain analysis because it helps in aligning the organizational goals to the customer (Donaldson, et. al 2006). Since the discussion is revolving around improving firm performance, a project targeted at quality improvement aimed at improving firm performance must be aligned with customer requirements.

Not surprisingly, virtually every industry size considers alignment with customer requirements as a major factor regarding the success of a quality improvement project. Kumar \& Antony (2008) positively associate it with SMEs while Antony \& Desai (2009) do so with regards to large enterprises. Others such as Banuelas Coronado \& Antony (2002) abstain from associating with any specific size of industry.

\section{Use of Quality Tools}

The immediate goal of six-sigma is defect reduction (Raisinghani et al. 2005). As stated in the introduction, one of the definitions of quality is conformance to requirements. For a manufacturing company, six-sigma is often defined as 3.4 rejects per million parts produced (Pande, Neuman \& Cavanagh 2000). These reject rates are measured and controlled using various quality tools such as statistical process control, pareto charts, fish bone analysis, house of quality, failure mode and effect analysis, etc. While these tools are an integral part of achieving six-sigma, implementing them requires specialized knowledge (Antony \& Banuelas 2002).

Since these tools are integral to achieving six-sigma, some authors have chosen to 
completely ignore mentioning them. This can be attributed to the fact that they are so mainstream that they are considered common knowledge. It is like saying "grass is green". Understandably, however, authors for all three categories have identified the use of quality tools as a major success factor.

\section{Willingness to Change (Change Management)}

Sometimes resistance to change is the most important factor that derails an idea. Consider the time when computers were first introduced into the workplace. While they were primarily designed to ease an employee's workload, their introduction was seen as a threat. It is also sometimes referred to as "clash of the veterans" (Zemke, Raines \& Filipczak 2000).

Six-sigma required a cultural shift in General Electric which meant telling 20,000 employees to work in a way that is different to what they have been doing for many years (Hendricks \& Kelbaugh 1998). Since this cultural change is extremely necessary, it is no surprise companies that are beginning to grow (SMEs) see it as a very important part of their business (Kumar, Antony \& Douglas 2009). Not surprisingly, it has been given importance across the board with studies considering both large enterprises (Antony, Gijo \& Childe 2012) and a mix of companies involving both SMEs and large enterprises (Tkáč \& Lyócsa 2010).

\section{Supporting Infrastructure}

Studies have shown that sustainability of improvement can be challenging. It is necessary for organizations to build a sustaining infrastructure and making improvement in the business process (Snee \& Hoerl 2003). Since, SMEs are most prone to consider short-term results over long term strategies, authors have stressed heavily on having a sustainable improvement infrastructure in place (Kumar, Antony \& Douglas 2009). Not surprisingly, authors who have not associated with any particular industry size or are associated with large enterprises also give it its due importance by recognizing supporting infrastructure as an important success factor for achieving sixsigma (Tkáč \& Lyócsa 2010).

\section{Alignment with Business Strategy}

Whenever a business enterprise is established, it employs a business model, enabling it to have a unique competitive advantage (Teece 2010). This model is part of the organization's overall strategy; what it aims to achieve and how it plans to get there. Since six-sigma is a holistic approach, its integration into the overall business strategy is termed important. Antony \& Banuelas (2002) who state that six-sigma is itself an improvement strategy, explain this. It gives the organization a unique competitive advantage as it improves profitability and drives out waste. Others, however, have cautioned that organizations must not look at it as the sole contributor. Kwak \& Anbari (2006) for example, have cautioned that organizations must not look at six-sigma as the universal solution to all business problems. To better understand the principles, they must acknowledge the strengths and weaknesses of the six- sigma program.

Since SMEs need to find unique niche markets to be successful, it is no surprise that all the authors cited in this review; those who have conducted research on SMEs consider it critical to align six-sigma to the overall business strategy (Antony, Kumar \& Labib 2008; Kumar \& Antony 2008; Kumar, Antony \& Douglas 2009; Shokri, Waring \& Nabhani 2016). And not surprisingly, it has been favoured by both large enterprises (Hendricks \& Kelbaugh 1998) and by authors who choose to be neutral with regards to the size of the industry they conducted research in (Banuelas Coronado \& Antony 2002).

\section{Visible Cost Saving}

The primary purpose of a business is to maximize shareholder wealth. What better way to do it than reducing the cost it takes to conceive a product? Hahn et al. (1999) seems to agree while presenting numbers from Motorola, General Electric and Allied 
Signal with reported savings of $\$ 940$ million, $\$ 1.75$ billion and $\$ 1.5$ billion respectively! All three companies embraced the six-sigma methodology and the results are phenomenal by any estimates.

With heightened competition and globalization, companies with a large presence often struggle to find a competitive advantage. When General Electric first incorporated the six-sigma program, the company ended up investing close to a billion dollars. This investment made it possible for a phenomenal increase in profits - three quarters of a billion dollars over the initial investment (Hahn et al. 1999). Not surprisingly, large enterprises that are beginning to enter closely contested markets have to be careful while making investments. While the six- sigma program is time consuming in terms of achieving results in its entirety, it is essential to report some form of visible cost saved in the initial years for the management to seriously consider it (Antony, Gijo \& Childe 2012). While SMEs largely seem uninterested, the authors who chose to remain neutral seemed to agree with the importance of visible cost savings
(Hahn, Doganaksoy \& Hoerl 2000).

It was observed that the list of factors kept increasing with no real correlation between the sizes of the organization. While some research was directed towards large enterprises, other was directed at specifically SMEs. Some authors, however, chose to remain neutral with little or no emphasis on the size of the organization.

\section{Implications for Various Organizations}

A further analysis reveals the importance of these factors by the size of the industry.

\section{General/Unspecified organization size}

The top five factors for the general/unspecified category were Employee Education/Training (94\%), Top Management Commitment (89\%) and Project Selection, Employee Involvement/Communication and Project Management/Leadership at 67\%.

Detailed analysis of the factors for the general/unspecified category is illustrated in the table below.

Table 2: Analysis of general/unspecified industries

\begin{tabular}{|l|c|}
\hline Factor & Percentage \\
\hline Employee Education/Training & $94 \%$ \\
\hline Top Management Commitment & $89 \%$ \\
\hline Project Selection & $67 \%$ \\
\hline Employee Involvement/Communication & $67 \%$ \\
\hline Project Management/Leadership & $67 \%$ \\
\hline Alignment with Customer Requirements & $56 \%$ \\
\hline Use of Quality Tools & $50 \%$ \\
\hline Patience to Achieve Results & $44 \%$ \\
\hline Willingness to change/Change Management & $39 \%$ \\
\hline Supporting Infrastructure & $33 \%$ \\
\hline Alignment with Business Strategy & $28 \%$ \\
\hline Visible Cost Saving & $17 \%$ \\
\hline Availability of Data & $17 \%$ \\
\hline Quality Awareness & $17 \%$ \\
\hline Depth of Analysis & $17 \%$ \\
\hline Integration of Suppliers & $11 \%$ \\
\hline Time Length of QMS and TQM & $11 \%$ \\
\hline Relationship between ISO 9000 \& TQM & $11 \%$ \\
\hline
\end{tabular}


Considering the number of papers that have been cited for general/unspecified industries is substantial, the percentages are also quite meaningful. A clear prioritization can be seen.

\section{Large Enterprises}

A similar analysis reveals the following top six factors for large enterprises. The results indicated that Project Selection and Alignment with Customer Requirements topped the factors at (83\%), followed by Employee Education/Training, Senior Management Commitment, Use of Quality Tools and Visible Cost Saving at 67\% each.

\section{Table3: Percentage analysis for Large Enterprises}

\begin{tabular}{|l|c|}
\hline Factor & Percentage \\
\hline Project Selection & $83 \%$ \\
\hline Alignment with customer requirements & $83 \%$ \\
\hline Employee Education/Training & $67 \%$ \\
\hline Top Management Commitment & $67 \%$ \\
\hline Use of quality tools & $67 \%$ \\
\hline Visible cost saving & $67 \%$ \\
\hline Project Management/Leadership & $50 \%$ \\
\hline Willingness to change/ Change Management & $50 \%$ \\
\hline Alignment with business strategy & $50 \%$ \\
\hline Employee Involvement/Communication & $33 \%$ \\
\hline Patience to Achieve Results & $33 \%$ \\
\hline Supporting infrastructure & $33 \%$ \\
\hline Availability of data & $33 \%$ \\
\hline Quality Awareness & $17 \%$ \\
\hline Depth of Analysis & $17 \%$ \\
\hline Integration of suppliers & $17 \%$ \\
\hline Time Length of QMS and TQM & $0 \%$ \\
\hline Relationship between ISO 9000 \& TQM & $0 \%$ \\
\hline
\end{tabular}

\section{Small and Medium Enterprises}

Due to the lower citing of SMEs in the reviewed works, many of the factors resulted with equal results, with the leading seven being Employee Education/Training, Senior Management
Commitment,

Employee Involvement/Communication and Alignment with Business Strategy at (100\%). This was followed by Project Selection, Willingness to Change and Supporting Infrastructure at (75\%) each.

Table 4: Percentage Analysis for SMEs

\begin{tabular}{|l|c|}
\hline Factor & Percentage \\
\hline Employee Education/Training & $100 \%$ \\
\hline Top Management Commitment & $100 \%$ \\
\hline Employee Involvement/Communication & $100 \%$ \\
\hline Alignment with Business Strategy & $100 \%$ \\
\hline Project Selection & $75 \%$ \\
\hline Willingness to Change/ Change Management & $75 \%$ \\
\hline Supporting Infrastructure & $75 \%$ \\
\hline Use of Quality Tools & $50 \%$ \\
\hline Project Management/Leadership & $25 \%$ \\
\hline Alignment with Customer Requirements & $25 \%$ \\
\hline
\end{tabular}

Syed Talib Haider, Hiyam Al-Kilidar and Rene Leveaux (2018), The Journal of Organizational Management Studies,DOI: 10.5171/2018.517249 


\begin{tabular}{|l|c|}
\hline Availability of Data & $25 \%$ \\
\hline Quality Awareness & $25 \%$ \\
\hline Patience to Achieve Results & $0 \%$ \\
\hline Visible Cost Saving & $0 \%$ \\
\hline Depth of Analysis & $0 \%$ \\
\hline Integration of Suppliers & $0 \%$ \\
\hline Time Length of QMS and TQM & $0 \%$ \\
\hline Relationship between ISO 9000 \& TQM & $0 \%$ \\
\hline
\end{tabular}

As with large enterprises, a similar problem exists with SMEs. Due to lack of available research in the area, it is very difficult to draw highly meaningful conclusions. However, it does give some indication about the priorities of SMEs in the manufacturing sector.

\section{Conclusion}

A total of 28 research papers from various countries were analyzed. 18 papers were related to the general/unspecified category, while 6 were associated with large enterprises and only 4 were related to SMEs.

The challenge of assessing the hypothesis was the number of papers that were included for SMEs and large enterprises in this study (four and six respectively). This is too small to draw significant and meaningful conclusions. However, all factors that are considered important by SMEs were also considered important by large enterprises. While some factors identified by large enterprises to be important were not even considered by SMEs. This could be attributed to the lack of available research specifically targeting large or SMEs.

While this study is by no means comprehensive, it does show that six-sigma can be implemented in organizations regardless of their size. It also shows the lack of available research differentiating emphasis on organisation size. As has been demonstrated, the dynamics of SMEs and Large Enterprises are quite different. With better research, even more conclusions that are meaningful may be achieved.

\section{Future work}

Through this review, it is identified that further research is required for SMEs as SMEs form a vital component of a country's economy. While this work provides a guide for a better understanding of where resources should be directed, a deeper understanding of the factors critical to the success of the six-sigma program further research is necessary.

\section{References}

1. ABS 2016, 8165.0 - Counts of Australian Businesses, including Entries and Exits, Jun 2011 to Jun 2015, viewed 16/10/16, http://www.abs.gov.au/AUSSTATS/abs@. nsf/Lookup/8165.0Main+Features1Jun\%2 02011\%20to\%20Jun\%202015?OpenDocu ment

2. Antony, J. \& Banuelas, R. 2002, 'Key ingredients for the effective implementation of Six Sigma program', Measuring business excellence, vol. 6, no. 4, pp. 20-7.

3. Antony, J. \& Desai, D.A. 2009, 'Assessing the status of Six Sigma implementation in the Indian industry: results from an exploratory empirical study', Management Research News, vol. 32, no. 5, pp. 413-23.

4. Antony, J., Douglas, A. \& Antony, F.J. 2007, 'Determining the essential characteristics of Six Sigma Black Belts: Results from a pilot study in UK manufacturing companies', TQM Magazine, vol. 19, no. 3, pp. 274-81.

5. Antony, J., Gijo, E.V. \& Childe, S.J. 2012, 'Case study in Six Sigma methodology: Manufacturing quality improvement and guidance for managers', Production Planning and Control, vol. 23, no. 8, pp. 624-40.

6. Antony, J., Kumar, M. \& Labib, A. 2008, 'Gearing Six Sigma into UK manufacturing SMEs: results from a pilot study', Journal of 
the Operational Research Society, vol. 59, no. 4, pp. 482-93.

7. Banuelas Coronado, R. \& Antony, J. 2002, 'Critical success factors for the successful implementation of six sigma projects in organisations', The TQM magazine, vol. 14, no. 2, pp. 92-9.

8. Banuelas, R., Antony, J. \& Brace, M. 2005, 'An application of Six Sigma to reduce waste', Quality and Reliability Engineering International, vol. 21, no. 6, pp. 553-70.

9. Bower, J.L. 1970, 'Managing the resource allocation process: A study of corporate planning and investment'.

10.Brady, J.E. \& Allen, T.T. 2006, 'Six Sigma literature: a review and agenda for future research', Quality and reliability engineering International, vol. 22, no. 3, pp. 335-67.

11.Bullen, C.V. \& Rockart, J.F. 1981, 'A primer on critical success factors'. Cambridge, MA, Center for Information Systems Research, Massachusetts Institute of Technology, Massachusetts (1981)

12.Cooke-Davies, T. 2002, 'The "real" success factors on projects', International journal of project management, vol. 20, no. 3, pp. 185-90.

13.Crosby, P.B. \& Free, Q.I. 1979, 'The art of making quality certain', New York: New American Library, vol. 17. Donaldson, K.M., Ishii, K. \& Sheppard, S.D. 2006, 'Customer value chain analysis', Research in Engineering Design, vol. 16, no. 4, pp. 17483.

14.Douglas, A., Douglas, J. \& Ochieng, J. 2015, 'Lean Six Sigma implementation in East Africa: Findings from a pilot study', TQM Journal, vol. 27, no. 6, pp. 772-80.

15.Fredericks, J.O. \& Salter II, J.M. 1998, 'What does your customer really want?', Quality Progress, vol. 31, no. 1, p. 63.

16.Freund, Y.P. 1988, 'Critical success factors', Planning Review, vol. 16, no. 4, pp. 20-3.

17.Giannetti, C. \& Ransing, R.S. 2016, 'Risk based uncertainty quantification to improve robustness of manufacturing operations', Computers \& Industrial Engineering, vol. 101, pp. 70-80.
18.Gijo, E. \& Rao, T.S. 2005, 'Six Sigma implementation-hurdles and more hurdles', Total Quality Management \& Business Excellence, vol. 16, no. 6, pp. 7215.

19.Gilmore, H.L. 1974, 'Product conformance cost', Quality progress, vol. 7, no. 5, pp. 16-9.

20.Gray, J. \& Anantatmula, V. 2009, 'Managing Six Sigma projects through the integration of Six Sigma and project management processes', International journal of six sigma and competitive advantage, vol. 5, no. 2, pp. 127-43.

21.Gronroos, C. 1982, 'Strategic management and marketing in the service', Boston: Management and Marketing. Hahn, G.J. 2005, 'Six Sigma: 20 key lessons learned', Quality and Reliability Engineering International, vol. 21, no. 3, pp. 225-33.

22.Hahn, G.J., Doganaksoy, N. \& Hoerl, R. 2000, 'The evolution of six sigma', Quality Engineering, vol. 12, no. 3, pp. 317-26.

23.Hahn, G.J., Hill, W.J., Hoerl, R.W. \& Zinkgraf, S.A. 1999, 'The impact of Six Sigma improvement-a glimpse into the future of statistics', The American Statistician, vol. 53, no. 3, pp. 208-15.

24.Harry, M.J. 1998, 'Six Sigma: a breakthrough strategy for profitability', Quality progress, vol. 31, no. 5, p. 60.

25.Hassan, R., Marimuthu, M. \& Mahinderjit-Singh, M. 2016, 'Application of Six-Sigma for process improvement in manufacturing industries: A case study', International Business Management, vol. 10, no. 5, pp. 676- 91 .

26. Hendricks, C.A. \& Kelbaugh, R.L. 1998, 'Implementing six sigma at GE', The Journal for Quality and Participation, vol. 21, no. 4, p. 48.

27. Hua, H., Chin, K., Sun, H. \& Xu, Y. 2000, 'An empirical study on quality management practices in Shanghai manufacturing industries', Total quality management, vol. 11, no. 8, pp. 1111-22.

28.Juran, J.M. 1988, 'The quality function', JJM \& FM Gryna (Eds.), Juran's Quality Control Handbook, pp. 2.1-2.13. 
29.Kaynak, H. 2003, 'The relationship between total quality management practices and their effects on firm performance', Journal of operations management, vol. 21 , no. 4 , pp. 405-35.

30.Kumar, M. \& Antony, J. 2008, 'Comparing the quality management practices in UK SMEs', Industrial Management and Data Systems, vol. 108, no. 9, pp. 1153-66.

31.Kumar, M., Antony, J. \& Douglas, A. 2009, 'Does size matter for Six Sigma implementation? Findings from the survey in UK SMEs', The TQM journal, vol. 21, no. 6, pp. 623-35.

32.Kumar, M., Antony, J. \& Rae Cho, B. 2009, 'Project selection and its impact on the successful deployment of Six Sigma', Business Process Management Journal, vol. 15 , no. 5, pp. $669-86$.

33.Kwak, Y.H. \& Anbari, F.T. 2006, 'Benefits, obstacles, and future of six sigma approach', Technovation, vol. 26, no. 5, pp. 708-15.

34.Leidecker, J.K. \& Bruno, A.V. 1984, 'Identifying and using critical success factors', Long range planning, vol. 17, no. 1, pp. 23-32.

35.Linderman, K., Schroeder, R.G., Zaheer, S. \& Choo, A.S. 2003, 'Six Sigma: a goaltheoretic perspective', Journal of Operations management, vol. 21, no. 2, pp. 193-203.

36.Meade, L.M. \& Presley, A. 2002, 'R\&D project selection using the analytic network process', IEEE transactions on engineering management, vol. 49 , no. 1 , pp. 59-66.

37.Pande, P.S., Neuman, R.P. \& Cavanagh, R.R. 2000, The six sigma way, McGraw-Hill.

38. Raisinghani, M.S., Ette, H., Pierce, R., Cannon, G. \& Daripaly, P. 2005, 'Six Sigma: concepts, tools, and applications', Industrial management \& Data systems, vol. 105 , no. 4 , pp. 491-505.

39.Reeves, C.A. \& Bednar, D.A. 1994, 'Defining quality: alternatives and implications', Academy of management Review, vol. 19, no. 3, pp. 419-45.
40.Rockart, J.F. 1978, 'Chief executives define their own data needs', Harvard business review, vol. 57, no. 2, pp. 81-93.

41.Samson, D. \& Terziovski, M. 1999, 'The relationship between total quality management practices and operational performance', Journal of operations management, vol. 17 , no. 4, pp. 393-409.

42.Shokri, A., Waring, T.S. \& Nabhani, F. 2016, 'Investigating the readiness of people in manufacturing SMEs to embark on Lean Six Sigma projects: An empirical study in the German manufacturing sector', International Journal of Operations and Production Management, vol. 36, no. 8, pp. 850-78.

43.Snee, R.D. \& Hoerl, R.W. 2003, Leading Six Sigma: a step-by-step guide based on experience with GE and other Six Sigma companies, Ft Press.

44.Teece, D.J. 2010, 'Business models, business strategy and innovation', Long range planning, vol. 43, no. 2, pp. 172-94.

45.Tkáč, M. \& Lyócsa, Š. 2010, 'On the evaluation of Six Sigma projects', Quality and reliability engineering international, vol. 26, no. 1, pp. 115-24.

46. Tlapa, D., Limon, J., García-Alcaraz, J.L., Baez, Y. \& Sánchez, C. 2016, 'Six Sigma enablers in Mexican manufacturing companies: a proposed model', Industrial Management \& Data Systems, vol. 116, no. 5, pp. 926-59.

47.Tsai, W.-C. \& Tai, W.-T. 2003, 'Perceived importance as a mediator of the relationship between training assignment and training motivation', Personnel Review, vol. 32, no. 2, pp. 151-63.

48.Van Dyk, D.J. \& Pretorius, L. 2014, 'A systems thinking approach to the sustainability of quality improvement programmes', South African Journal of Industrial Engineering, vol. 25, no. 1, pp. 71-84.

49.Wiley, C. 1997, 'What motivates employees according to over 40 years of motivation surveys', International Journal of Manpower, vol. 18, no. 3, pp. 263-80.

50.Zemke, R., Raines, C. \& Filipczak, B. 2000, Generations at work: Managing the 
clash of Veterans, Boomers, Xers, and Nexters in your workplace, Amacom New York, NY.

51.Zu, X., Robbins, T.L. \& Fredendall, L.D. 2010, 'Mapping the critical links between organizational culture and TQM/Six Sigma practices', International journal of production economics, vol. 123, no. 1, pp. 86-106. 